\title{
Leptin receptor expression and in vitro leptin actions on prostaglandin release and nitric oxide synthase activity in the rabbit oviduct
}

\author{
M Zerani, C Boiti ${ }^{1}$, C Dall'Aglio ${ }^{2}$, L Pascucci ${ }^{2}$, M Maranesi $^{1}$, \\ G Brecchia ${ }^{1}$, C Mariottini ${ }^{1}$, G Guelfi ${ }^{1}$, D Zampini ${ }^{1}$ \\ and A Gobbetti
}

Dipartimento di Biologia Molecolare, Cellulare e Animale, Università di Camerino, via F Camerini 1, 62032 Camerino, Italy

${ }^{1}$ Dipartimento di Scienze Biopatologiche Veterinarie, Laboratorio di Biotecnologie Fisiologiche, Università di Perugia, S Costanzo 4, 06100 Perugia, Italy

${ }^{2}$ Dipartimento di Scienze Biopatologiche Veterinarie, Sezione di Anatomia, Università di Perugia, S Costanzo 4, 06100 Perugia, Italy

(Requests for offprints should be addressed to M Zerani; Email: massimo.zerani@unicam.it)

\begin{abstract}
In this study, we have examined the presence and the distribution of receptors for leptin (Ob-R) in the oviduct of rabbits, and the effects of leptin on the release of prostaglandin (PG) F2 $\alpha$ and PGE2 and on the activity of nitric oxide (NO) synthase (NOS) by oviducts cultured in vitro. Rabbits were killed during the follicular phase and the oviducts were incubated in vitro with leptin, PGF2 $\alpha$, PGE2, NO donor and inhibitors of NOS and cyclooxigenase (COX). Using immunohistochemistry, Ob-Rlike positive reaction was observed only in the cytoplasm of secretory cells, having stronger intensity in the in-
\end{abstract}

fundibulum and ampulla tracts than in the isthmus. Both leptin and NO donor inhibited PGE2 release, whereas they enhanced PGF2 $\alpha$ release; NOS inhibitor alone or with leptin increased PGE2 and decreased PGF2 $\alpha$ production; NOS activity was enhanced by leptin, while PGs did not affect this enzyme. This study suggests that the oviduct could be a potential target for endocrine regulation by leptin, whose circulating levels may act as a metabolic signal modulating oviductal PG release through mediation of the NOS/NO system.

Journal of Endocrinology (2005) 185, 319-325

\section{Introduction}

The oviduct plays a key role in the reproductive process by enabling gamete transport, oocyte fertilization and early embryonic development through fine regulation of oviductal smooth muscle contractility, ciliar activity and synthesis of oviductal factors (Sayegh \& Mastroianni 1991). The endocrine and paracrine control mechanism of oviductal functions involves several factors including ovarian steroids (Wollenhaupt et al. 2002), prostaglandin (PG) F2 $\alpha$ and PGE2 (Harper 1988), nitric oxide (NO) (Rosselli et al. 1996, Perez Martinez et al. 1997), growth factors (Makarevich \& Sirotkin 1997) and cytokines (Wijayagunawardane et al. 2003).

Recent evidence suggests that leptin, a $16.4 \mathrm{kDa}$ cytokine encoded by the obese gene $(o b)$ and synthesized by adipocytes (Zhang et al. 1994) and many tissues of the female reproductive system (Masuzaki et al. 1997, SmithKirwin et al. 1998, Gonzalez et al. 2000, Ryan et al. 2002), is involved not only in the regulation of food intake, energy expenditure and metabolism (Barb 1999) but also in the control of reproductive functions (Zhang et al. 1994,
Chehab et al. 1996, Clark \& Henry 1999, Cunningham et al. 1999, Brann et al. 2002, Williams et al. 2002).

Within the reproductive system, the action of leptin is exerted both centrally, in the hypothalamus and pituitary, and peripherally through binding with its specific receptor $(\mathrm{Ob}-\mathrm{R})$, which has been identified in various tissues of the gonadic axis of several species (Spicer \& Francisco 1997, Finn et al. 1998, Jin et al. 2000, Kitawaki et al. 2000, Koshiba et al. 2001, Ryan et al. 2002) and recently also in the corpora lutea of rabbits (Zerani et al. 2004). These observations, together with the finding of the effects induced by leptin in different in vitro systems based on cells from the reproductive tract, suggest that leptin is involved in a large array of regulatory actions required for normal reproductive functions. In particular, given the wide distribution of $\mathrm{Ob}-\mathrm{R}$ in different sites of the reproductive axis, leptin may act as the critical link between adipose tissue and the reproductive system, indicating whether adequate energy reserves are present for normal reproductive function (Moschos et al. 2002).

All these reasons prompted us to verify, using immunohistochemistry, whether receptors for leptin also exist in 
the oviduct of rabbits. We also examined, using in vitro studies, the possible effects of leptin on NO synthase (NOS) activity and on PGF2 $\alpha$ and PGE2 release by the oviduct.

\section{Materials and Methods}

Animals, hormonal regimen and tissue collection

Sexually mature unmated New Zealand White (HY/CR strain) rabbits (Charles River Italia, Lecco, Italy) of 5 months of age, weighing $3 \cdot 5-3 \cdot 8 \mathrm{~kg}$, were caged individually in quarters at the University of Perugia Central Animal Facility. The animals were maintained under controlled conditions of light (14 h light:10 h darkness) and temperature $\left(18{ }^{\circ} \mathrm{C}\right)$ and provided with commercial rabbit chow and tap water ad libitum.

Rabbits were killed during the follicular phase by cervical dislocation and reproductive tracts, promptly removed from each animal, were thoroughly washed with saline and transported to the nearby laboratory in glass containers filled with saline. Within a few minutes, the oviducts were separated from the utero-tubal junction and carefully trimmed of fat with fine forceps. The oviducts harvested from each rabbit were then immediately processed for immunohistochemistry and in vitro studies.

The protocols involving the care and the use of animals for these experiments were approved by the Bioethic Committee of the University of Perugia.

\section{Immunohistochemistry of $\mathrm{Ob}-\mathrm{R}$}

For the immunohistochemical studies, specimens were collected from the infundibulum, ampulla and isthmus regions of the uterine tubes of three rabbits.

The specimens were fixed by immersion in $4 \%$ formaldehyde in phosphate-buffered saline ( $\mathrm{pH} \mathrm{7 \cdot 4)}$ (PBS) for $24 \mathrm{~h}$ at room temperature, then dehydrated and routinely embedded in paraffin. On $6 \mu \mathrm{m}$ thick sections, the presence and the distribution of $\mathrm{Ob}-\mathrm{R}$ were identified by an immunohistochemical technique, using the avidin-biotinperoxidase complex and a diaminobenzidine-nickel solution (Vector Laboratories, Burlingame, CA, USA) to visualize the reaction site.

The primary antibody used in the immunohistochemical procedures was a mouse anti-Ob-R (1:50; sc-8391; Santa Cruz Biotechnology, Santa Cruz, CA, USA). This antibody is recommended for the detection of short and long forms of $\mathrm{Ob}-\mathrm{R}$, as reported in the manufacturer's datasheet.

Briefly, sections were dewaxed in xylene and hydrated through a series of graded ethanol and were microwaved for $5 \mathrm{~min}$ at $750 \mathrm{~W}$ in $10 \mathrm{mM}$ citric acid (pH 6.0) for antigen retrieval. Afterwards, sections were incubated with normal goat serum at room temperature in a moist chamber for $30 \mathrm{~min}$ and then overnight with the primary antibody in the same conditions.
The primary antibody was washed off in three successive PBS washes, and then the sections were incubated with the secondary antibody (a biotinylated goat antimouse, 1:200 in PBS; Vector Laboratories) and then with the avidin-biotin-peroxidase complex (1:2500 in PBS; ABC Elite Kit; Vector Laboratories), both for $30 \mathrm{~min}$ at room temperature.

Sections in which the primary antibody was omitted or substituted by pre-immune mouse $\gamma$-globulin were used for the negative control of unspecific staining.

\section{In vitro incubations}

Tracts of the ampullary and infundibulum regions of the oviducts, approximately $1 \mathrm{~cm}$ in length, were randomly distributed (one segment/well) into incubation wells (Becton Dickinson Co., Clifton, NJ, USA) in $1 \mathrm{ml}$ culture medium 199 with Earles' balanced salt solution (GIBCO, Grand Island, NY, USA) containing $2 \cdot 2 \mathrm{mg} / \mathrm{ml}$ sodium bicarbonate, $2.3 \mathrm{mg}$ HEPES (Sigma, St Louis, MO, USA) and 3\% BSA (Sigma). Before treatment, the oviducts were 'opened' longitudinally inside each well using fine forceps. Each incubation set of wells was divided into 12 experimental groups of four wells as follows: (i) medium alone as control; (ii) leptin (100 nM; Calbiochem Corp., San Diego, CA, USA); (iii) PGF2 $\alpha$ (1 $\mu$ M; Sigma); (iv) PGE2 (1 $\mu \mathrm{M}$; Sigma); (v) NO donor (sodium nitroprusside, $10 \mu \mathrm{M}$; Sigma); (vi) cyclo-oxigenase (COX) inhibitor (acetylsalicylic acid, $10 \mu \mathrm{M}$; Sigma); (vii) NOS inhibitor (N-nitro-L-arginine methyl ester, $10 \mu \mathrm{M}$; Calbiochem Corp.); (viii) leptin plus COX inhibitor; (ix) leptin plus NOS inhibitor; (x) PGF2 $\alpha$ plus NOS inhibitor; (xi) PGE2 plus NOS inhibitor; (xii) NO donor plus COX inhibitor. The culture plates were incubated at $37^{\circ} \mathrm{C}$ in air with $5 \%$ $\mathrm{CO}_{2}$ as reported elsewhere (Gobbetti et al. 1999, Boiti et al. 2000). The media of each well were collected after $6 \mathrm{~h}$ of incubation and stored immediately at $-20{ }^{\circ} \mathrm{C}$ for later determination of hormones. Each oviductal segment was weighed and stored immediately at $-20{ }^{\circ} \mathrm{C}$ for later determination of NOS activity. Preliminary evidence led to our choosing the incubation conditions and the minimum effective doses of the substances used in the present in vitro study (Fig. 1). For in vitro studies, segments from the infundibulum and ampulla were purposely used due to their higher expression for $\mathrm{Ob}-\mathrm{R}$.

\section{Determination of NOS activity}

NOS activity was determined in the same oviductal tracts used for in vitro incubations by monitoring the conversion of $\left[{ }^{3} \mathrm{H}\right] \mathrm{L}$-arginine into $\left[{ }^{3} \mathrm{H}\right] \mathrm{L}$-citrulline with the NOS detect assay kit (Alexis Corp., Läufelfingen, Switzerland) as previously described (Boiti et al. 2000). The oviduct specimen of each well was homogenized in $1 \mathrm{ml}$ cold fresh homogenization buffer $(50 \mathrm{mM}$ Tris, $1 \mathrm{mM}$ EDTA and $1 \mathrm{mM}$ EGTA, pH 7·4) and centrifuged at $20000 \boldsymbol{g}$ for 
Dose-Response curves

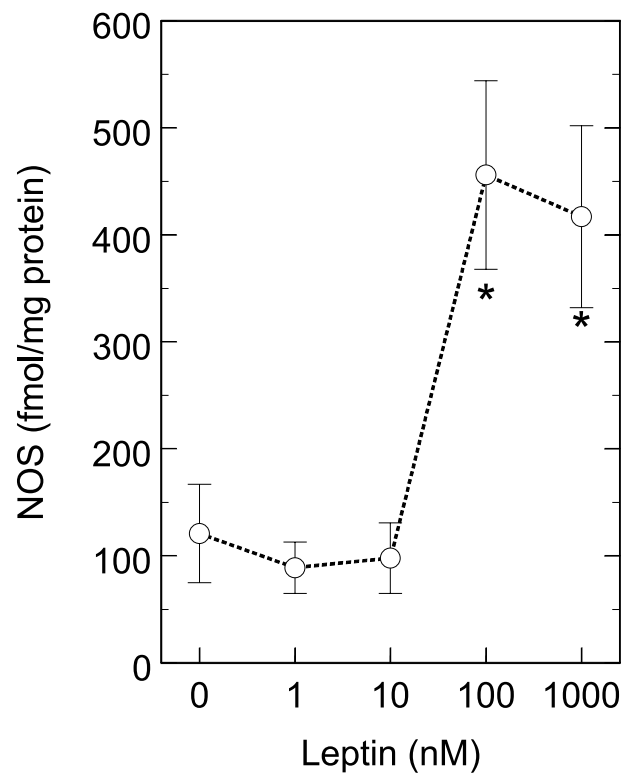

Dose-Response curves

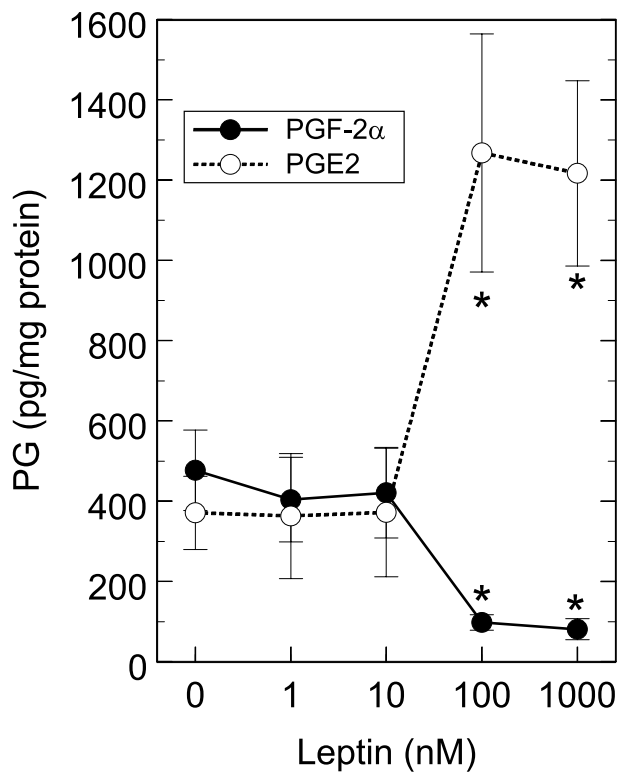

Figure 1 In vitro effects of increasing concentrations of leptin on total NOS activity (left), and release (right) of PGF2 $\alpha$ and PGE2 by oviducts of rabbits. Results are the means \pm S.D. of four replicate values. ${ }^{*} P \leq 0 \cdot 01$ (Student's $t$-test).

60 min at $4{ }^{\circ} \mathrm{C}$. Twenty-five microlitres of supernatant and $100 \mu \mathrm{l}$ incubation buffer $(1.5 \mathrm{mM} \mathrm{NADPH}$ and $1 \mathrm{mM} \mathrm{CaCl}{ }_{2}$ ) containing 150000 d.p.m. $\left[{ }^{3} \mathrm{H}\right] \mathrm{L}$-arginine (Sigma) were added to the incubation tube. After $30 \mathrm{~min}$ of incubation at room temperature, the enzymatic reaction was stopped by the addition of $2 \mathrm{ml}$ blocking buffer (20 mM HEPES and $2 \mathrm{mM}$ EDTA, pH 5.5). The mixture was applied to a pre-equilibrated column $(20 \mathrm{mM}$ sodium acetate, $2 \mathrm{mM}$ EDTA and $0 \cdot 2 \mathrm{mM}$ EGTA, pH 5.5; $1 \mathrm{~cm}$ diameter) containing $1 \mathrm{ml}$ Dowex AG50W-X8 (Sigma), and the material was eluted with $2 \mathrm{ml}$ water. $\left[{ }^{3} \mathrm{H}\right] \mathrm{L}-$ citrulline was quantified in a liquid scintillation system LS 1801 (Beckman Instruments, Fullerton, CA, USA). Additional determinations were performed in the presence of NOS inhibitor (N-nitro-L-arginine methyl ester) excess to verify the specificity of the assay for production of $\left.{ }^{3} \mathrm{H}\right] \mathrm{L}$-citrulline by NOS (data not shown). Protein concentration was determined by the Bio-Rad (Hercules, CA, USA) protein assay kit.

\section{Hormone RIA}

PGF2 $\alpha$ and PGE2 were determined in each medium sample using the RIA protocols previously reported (Boiti et al. 2000). Intra- and interassay coefficients of variation and minimum detectable dose were respectively: $7 \%, 14 \%$ and $16 \mathrm{pg}$ for PGF2 $\alpha$ and 9\%,16\% and $19 \mathrm{pg}$ for PGE2. PGF2 $\alpha$ and PGE2 antisera and non-radioactive hormones were purchased from Sigma. Tritiated hormones were purchased from Amersham International plc (Amersham, Bucks, UK).

\section{Statistics}

All data relative to PG release and enzyme activity were submitted to ANOVA followed by Student's $t$-test (Sokal \& Rohlf 1981).

\section{Results}

\section{Oviduct expression of $\mathrm{Ob}-\mathrm{R}$}

The cytoplasm of secretory cells was clearly stained and the $\mathrm{Ob}-\mathrm{R}$-like reactivity was more intense in the perinuclear and basal regions than in the apical cytoplasm (Fig. 2a, arrows). The intensity of staining for $\mathrm{Ob}-\mathrm{R}$ was stronger in the infundibulum and ampulla tracts than in the isthmus (Fig. 2a-c). Positive control sections were correctly stained, while no reactivity was observed in the sections where primary antibody was replaced with normal serum (data not shown).

In vitro cultured oviducts

PGs Both leptin and NO donor decreased PGF2 $\alpha$ $(P \leq 0 \cdot 01)$ but increased PGE2 $(P \leq 0 \cdot 01)$ release (Fig. 3$)$. 

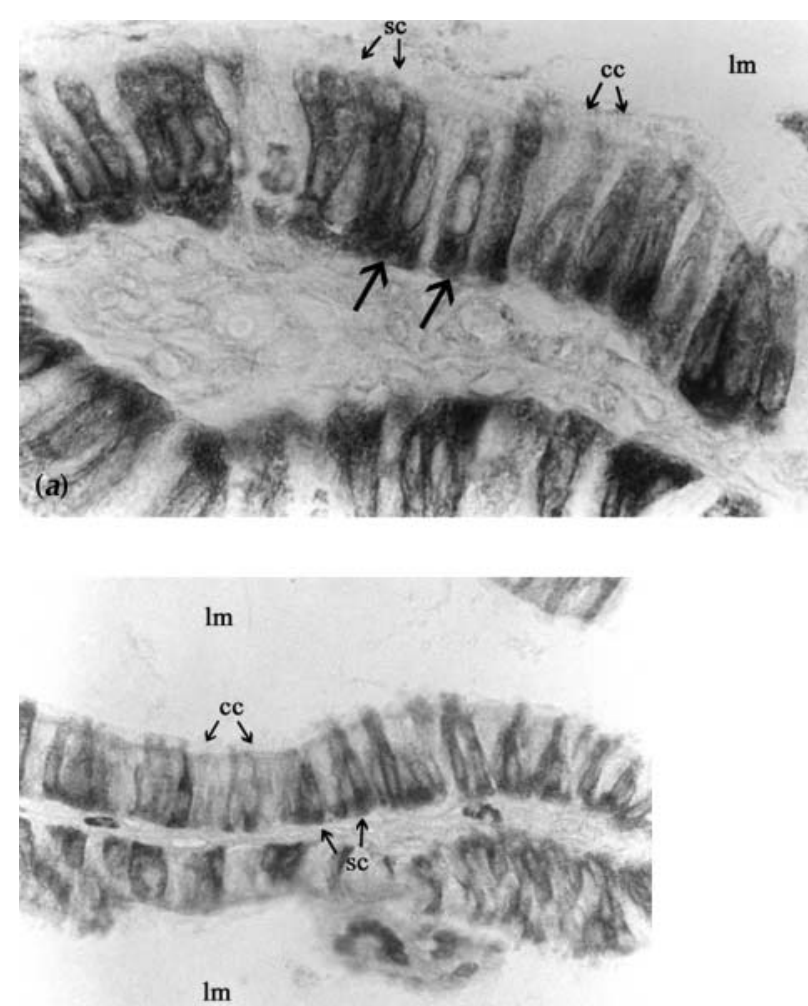

(b)

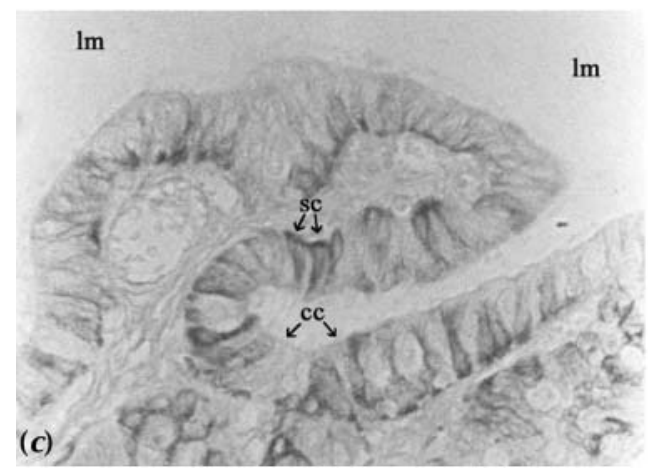

Figure 2 Immunohistochemical localization of Ob-R in different segments of the rabbit oviduct: (a) infundibulum, (b) ampulla and (c) isthmus. Strong positive reaction is shown especially in the cytoplasm of the epithelial secreting cells (sc), whereas it is less evident in ciliated cells (cc). The Ob-R-like immunoreaction was demonstrated all over the cell cytoplasm, but was particularly evident in the basal cell region ((a) larger arrows) opposite to the lumen $(\mathrm{Im})$, where it is more likely localized in the rough endoplasmic reticulum. Magnifications: (a) $1000 \times$; (b and c) $500 \times$.

NOS inhibitor alone or with leptin increased PGF2 $\alpha$ $(P \leq 0 \cdot 01)$ and decreased PGE2 $(P \leq 0 \cdot 01)$ release (Fig. 3$)$. The COX inhibitor decreased $\mathrm{PG}$ release $(P \leq 0 \cdot 01)$ in all experimental groups (Fig. 3). PGF2 $\alpha$ and PGE2 (a)

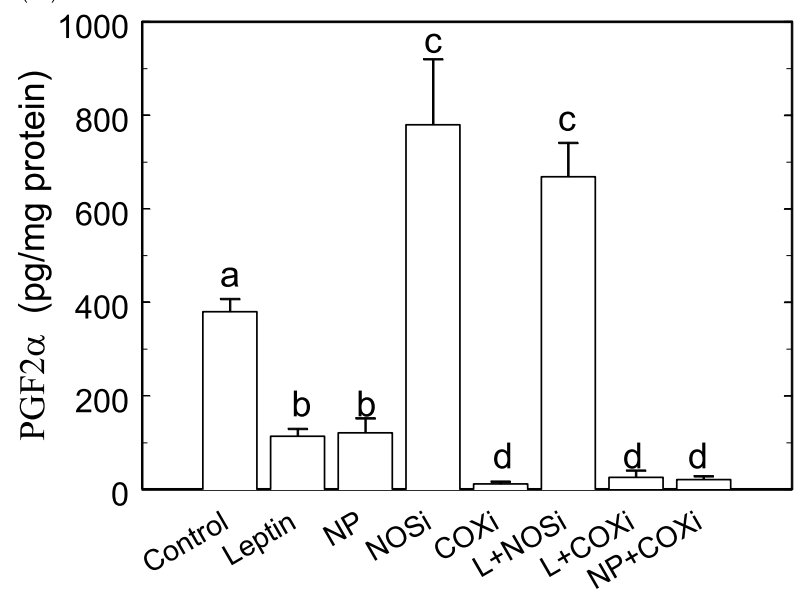

(b)

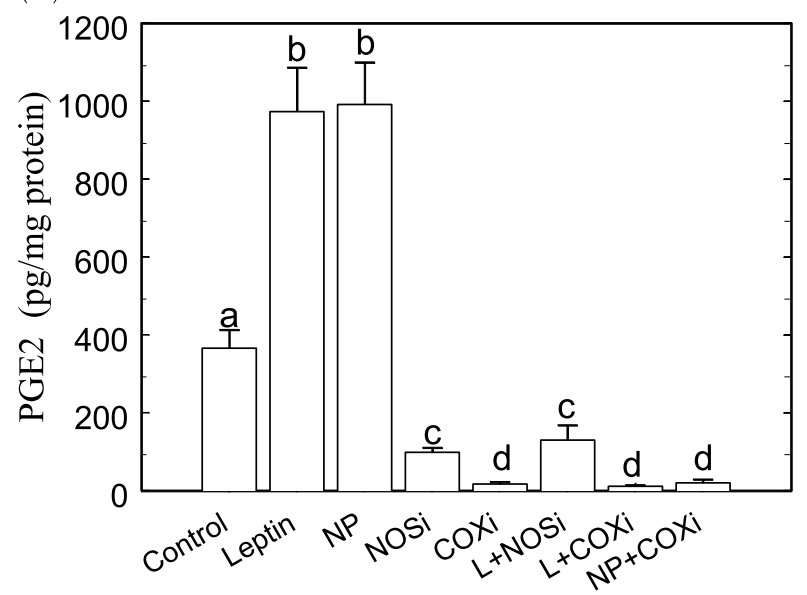

Figure 3 In vitro effects of leptin, $\mathrm{NO}$ donor (nitroprusside, NP), NOS inhibitor (NOSi), COX inhibitor (COXi), leptin plus NOSi $(\mathrm{L}+\mathrm{NOSi})$, leptin plus COXi $(\mathrm{L}+\mathrm{COX} \mathrm{i})$ and $\mathrm{NO}$ donor plus COXi $(\mathrm{NP}+\mathrm{COX}$ i) on (a) PGF2 $\alpha$ and (b) PGE2 release by rabbit oviducts. Results are the means \pm s.D. of five replicate values. Different letters above the bars indicate significantly different values $(P \leq 0 \cdot 01$, Student's $t$-test).

values (the experimental groups with COX inhibitor were not considered) were negatively correlated $(n=20$, $\mathrm{r}=-0.9821, P \leq 0.001)$.

NOS Leptin alone or co-incubated with COX inhibitor increased NOS activity $(P \leq 0 \cdot 01)$ (Fig. 4). The NOS inhibitor decreased NOS activity $(P \leq 0 \cdot 01)$ in all experimental groups (Fig. 4). PGF2 $\alpha$, PGE2 and the COX inhibitor did not affect NOS activity (Fig. 4). NOS and PGF2 $\alpha$ values (medium alone and leptin experimental groups only were considered) were negatively correlated $(n=8, \mathrm{r}=-0.9195, P \leq 0 \cdot 01)$. By contrast, NOS and PGE2 values were positively correlated $(n=8, \mathrm{r}=0.9468$, $P \leq 0 \cdot 01)$. 


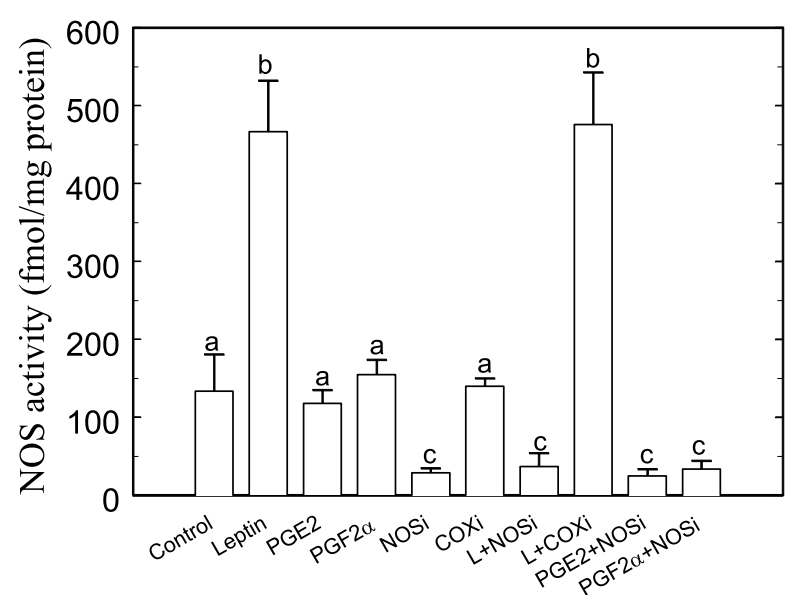

Figure 4 In vitro effects of leptin, PGE2, PGF2 $\alpha$, NOS inhibitor (NOSi), COX inhibitor (COXi), leptin plus NOSi $(\mathrm{L}+\mathrm{NOSi})$, leptin plus COXi (L+COXi), PGE2 plus NOSi (PGE2+NOSi) and PGF2 $\alpha$ plus NOSi (PGF2 $\alpha+\mathrm{NOSi}$ ) on total NOS activity by rabbit oviducts. Results are the means \pm S.D. of five replicate values. Different letters above the bars indicate significantly different values $(P \leq 0 \cdot 01$, Student's $t$-test).

\section{Discussion}

To the best of our knowledge, this is the first report to describe the presence and localization of the $\mathrm{Ob}-\mathrm{R}$ in the mammalian oviduct. Immunohistochemistry revealed that $\mathrm{Ob}-\mathrm{R}$-like positive staining was present in the cytoplasm of the secretory cells of the rabbit oviducts, whereas it was completely absent from smooth muscle cells. The intensity of Ob-R staining was stronger in the epithelial cells of the infundibulum and ampulla than in the junctional tract of the oviduct. This finding, however, should be regarded with care because of the intrinsic limitation of the immunohistochemical technique used.

The $\mathrm{Ob}-\mathrm{R}$ is a single membrane-spanning receptor and a member of the cytokine receptor superfamily (Sweeney 2002), which, upon binding with leptin, is internalized into specific cytoplasmic domains via clathrin-mediated endocytosis (Barr et al. 1999). Our immunohistochemical results have consistently shown a stronger Ob-R-like reaction in the basal cytoplasmic region of secretory cells where the rough endoplasmic reticulum is more likely localized. These findings are in agreement with recent reports which showed Ob-R-like immunoreactivity in the rough endoplasmic reticulum, Golgi apparatus and cytoplasmic matrix of hypothalamic neurones (Diano et al. 1998), glial cells (Funahashi et al. 2000), COS-7 cells (Barr et al. 1999) and different ovarian structures of rabbits (Zerani et al. 2004).

PGE2 and PGF2 $\alpha$ are the principal prostanoids produced in the endometrium, and regulate its function in an autocrine/paracrine manner (Sales \& Jabbour 2003). In particular, these PGs interact with smooth muscle and vascular receptors to control myometrial and vascular activity. PGE2 inhibits myometrial contractility and causes vasodilatation; by contrast, PGF2 $\alpha$ induces contractility and vasoconstriction (Sales \& Jabbour 2003). The present work suggests that leptin is a modulator of oviductal PG synthesis, given that this hormone inhibited PGF2 $\alpha$ release, whilst it stimulated that of PGE2. This role in PG synthesis regulation was also confirmed, although indirectly, by our recent findings showing an increase of PGF2 $\alpha$ release induced by leptin in rabbit corpora lutea (Zerani et al. 2004). Even if no direct data exist on the interaction between blood leptin concentration and subsequent successful implantation, the idea that leptin might affect fertility and fecundity, via oviductal PG synthesis, is intriguing.

The role of $\mathrm{NO}$ in the regulation of COX enzymes and their arachidonic-derived products are well known in both physiology and physiopathology (Salvemini 1997). Increasing evidence supports the hypothesis that the NOS/NO system mediates the effects of leptin on various mammalian tissues: arterial relaxation (Kimura et al. 2000), preovulatory luteinizing hormone and prolactin surges (Watanabe \& Sciöth 2001), lipolysis of white adipose tissue (Frühbeck \& Gomez-Ambrosi 2001), fluidity and rigidity of erythrocyte membranes (Tsuda et al. 2002) and growth hormone production by blood mononuclear cells (Dixit et al. 2003). In our in vitro study, we found that leptin affects PG release by rabbit oviduct via a NOSdependent mechanism. In fact, leptin increased NOS activity and $\mathrm{NO}$ donor mimicked the same effects of leptin on PG release, whereas the NOS inhibitor counteracted and reversed both leptin-dependent PGF2 $\alpha$ decrease and PGE2 increase. In agreement with these results, it has been found that the NOS inhibitor enhanced PGF2 $\alpha-$ induced contraction of the rat oviduct, proving that there is a basal release of $\mathrm{NO}$ which may reduce and/or modulate the contractile actions of PGF2 $\alpha$ (Perez Martinez et al. 1998). More recently, other studies have confirmed that NO inhibits prostanoid synthesis in the rat oviduct (Perez Martinez et al. 2000a). Differently from our study, these authors reported that NO decreases all prostanoids evaluated (6-keto-PGF2 $\alpha$, PGF2 $\alpha$, PGE2 and tromboxane B2). Perez Martinez et al. (2000b) also found that NO inhibition increases rat oviductal mobility and accelerates ovum transport, thus suggesting that NO could act as a paracrine signal between different layers of oviductal wall. In addition, Ribeiro et al. (2003) showed that the synthesis of COX metabolites is positively regulated by $\mathrm{NO}$ in the oestrogenized uterus of the rat.

Leptin acts through its binding to six isoform receptors (Ob-Ra-f), but only the long form $\mathrm{Ob}-\mathrm{Rb}$ has full signalling capabilities and is able to activate the janus kinase (JAK)/signal transducer and activator of transcription (STAT), which is the major pathway used by leptin to promote its effects (Sweeney 2002, Hegyi et al. 2004). 
However, some signalling events can be initiated by the short isoforms and/or involve other pathways, such as mitogen-activated protein kinase (MAPK) (Brann et al. 2002, Hegyi et al. 2004). Recently, we found $\mathrm{Ob}-\mathrm{R}$ in the corpora lutea of rabbits, where leptin was shown to use different intracellular signalling pathways in affecting progesterone and PGF2 $\alpha$, but not PGE2, release (Zerani et al. 2004). In fact, leptin inhibited progesterone production through the MAPK cascade, and enhanced PGF2 $\alpha$ release through the JAK/STAT pathway.

An increasing body of evidence unequivocally points to a close inter-link between nutrition and reproduction (Spicer \& Francisco 1997). Besides long-term food deprivation and starvation, two conditions well known for their negative effects on fertility, interestingly even short-term fasting has been shown to impair reproduction in different species (Bonanno et al. 2002, Steiner et al. 2003). In rabbits fed a restricted diet, peripheral plasma leptin concentrations are lower compared with animals fed ad libitum, especially during the compensatory growth phase after week 12 (Rommers et al. 2004).

It was recently suggested that leptin has a dual effect on the reproductive mechanisms of mammals, determined by different thresholds and by its site of activity (Caprio et al. 2001). Blood levels of leptin above a minimal threshold are necessary to activate the hypothalamus-pituitary-gonadal axis, trigger puberty and maintain normal reproductive function. Leptin excess above a certain threshold, such as found in obesity, might impair testicular and ovarian steroidogenesis and have deleterious effects on reproduction.

Taken together, the in vitro effects of leptin on the rabbit oviduct suggest that this organ could be a potential target for fine-tuned regulation by leptin, whose circulating levels, reflecting whole body energy store, may act as a metabolic signal either centrally and/or peripherally to switch on or off reproduction activity respectively.

\section{Acknowledgements}

This work was supported in part by a grant from Ministero Istruzione, Università e Ricerca (PRIN-Prot. 2003074002_003). The authors gratefully acknowledge the technical assistance by Mrs G Mancini for the immunohistochemical preparations and the revision of the English text by Dr James Burge of the Linguistic Institute of Camerino University. The authors declare that there is no conflict of interest that would prejudice the impartiality of this scientific work.

\section{References}

Barb CR 1999 The brain-pituitary-adipocyte axis: role of leptin in modulating neuronedocrine function. Journal of Animal Science $\mathbf{7 7}$ 1249-1257.
Barr VA, Lane K \& Taylor SI 1999 Subcellular localization and internalisation of the four human leptin receptor isoforms. Journal of Biological Chemistry 30 21416-21424.

Boiti C, Zerani M, Zampini D \& Gobbetti A 2000 Nitric oxide synthase and progesterone release by isolated corpora lutea of rabbit in early- and mid-luteal phase of pseudopregnancy are differently modulated by prostaglandin E-2 and prostaglandin F-2 $\alpha$ via adenylate cyclase and phospholipase C. Journal of Endocrinology 164 179-186.

Bonanno A, Brecchia G, Mazza F, Alabiso M, Zampini D \& Boiti C 2002 Effects of nutritional stress induced by short-term fasting on reproductive performance of rabbits does. Reproduction in Domestic Animals 37227.

Brann DW, Wade FM, Dhandapani KM, Mahesh VB \& Buchanan CD 2002 Leptin and reproduction. Steroids 67 95-104.

Caprio M, Fabbrini E, Isidori AM, Aversa A \& Fabbri A 2001 Leptin in reproduction. Trends in Endocrinology and Metabolism 12 65-72.

Chehab FF, Lim ME \& Lu R 1996 Correction of the sterility defect in homozygous obese female mice by treatment with the human recombinant leptin. Nature Genetics 12 318-320.

Clark IJ \& Henry BA 1999 Leptin and reproduction. Reviews of Reproduction 4 48-55.

Cunningham MJ, Clifton DK \& Steiner RA 1999 Leptin's actions on the reproductive axis: perspectives and mechanisms. Biology of Reproduction 60 216-222.

Diano S, Kalra SP \& Horvath TL 1998 Leptin receptor immunoreactivity is associated with the Golgi apparatus of hypothalamic neurones and glial cells. Journal of Neuroendocrinology 10 647-650.

Dixit VD, Mielenz M, Taub DD \& Parvizi N 2003 Leptin induces growth hormone secretion from peripheral blood mononuclear cells via a protein kinase $\mathrm{C}$ - and nitric oxide-dependent mechanism. Endocrinology 144 5595-5603.

Finn PD, Cunningham MJ, Pau K-YE, Spies HG, Clifton DK \& Steiner RA 1998 The stimulatory effect of leptin on the neuroendocrine reproductive axis of the monkey. Endocrinology 139 4652-4662.

Frühbeck G \& Gomez-Ambrosi J 2001 Modulation of the leptin-induced white adipose tissue lipolysis by nitric oxide. Cellular Signalling 13 827-833.

Funahashi H, Ryushi T, Mizushima H, Katoh S \& Shioda S 2000 Ultrastructural localization of the receptor for leptin in the rat hypothalamus. Hormones and Behavior 37 327-334.

Gobbetti A, Boiti C, Canali C \& Zerani M 1999 Nitric oxide synthase acutely regulates progesterone production by in vitro cultured rabbit corpora lutea. Journal of Endocrinology 160 275-283.

Gonzalez RR, Caballero-Campo P, Jasper M, Mercader A, Devoto L, Pellicer A \& Simon C 2000 Leptin and leptin receptor are expressed in the human endometrium and endometrial leptin secretion is regulated by the human blastocyst. Journal of Clinical Endocrinology and Metabolism 85 4883-4888.

Harper MJK 1988 Gamete and zygote transport. In The Physiology of Reproduction, pp 103-134. Eds E Knobil \& J Neill. New York: Raven Press.

Hegyi K, Fulop K, Kovacs K, Toth S \& Falus A 2004 Leptin-induced signal transduction pathways. Cell Biology International 28 159-169.

Jin L, Zhang S, Burguera BG, Couce ME, Osamura RY, Kulig E \& Lloyd RV 2000 Leptin and leptin receptor in rat and mouse pituitary cells. Endocrinology 141 333-339.

Kimura K, Tsuda K, Baba A, Kawabe T, Boh-oka S, Ibata M, Moriwaki C, Hano T \& Nishio I 2000 Involvement of nitric oxide in endothelium-dependent arterial relaxation by leptin. Biochemical and Biophysical Research Communications 273 745-749.

Kitawaki J, Koshiba H, Ishihara H, Kusuki I, Tsukamoto K \& Honjo H 2000 Expression of leptin receptor in human endometrium and fluctuation during the menstrual cycle. Journal of Clinical Endocrinology and Metabolism 85 1946-1950. 
Koshiba H, Kitawaki J, Ishihara H, Kado N \& Kusuki I, Tsukamoto K \& Honjo H 2001 Progesterone inhibition of functional leptin receptor mRNA expression in human endometrium. Molecular Human Reproduction 7 567-572.

Makarevich AV \& Sirotkin AV 1997 The involvment of the GH/IGF-I axis in the regulation of secretory activity by bovine oviduct epithelial cells. Animal Reproduction Science 48 197-207.

Masuzaki H, Ogawa Y, Sagawa N, Hosoda K, Matsumoto T, Mise H, Nishimura H, Yoshimasa Y, Tanaka I, Mori T \& Nakao K 1997 Nonadipose tissue production of leptin: leptin as a novel placenta-derived hormone in humans. Nature Medicine 3 1029-1033.

Moschos S, Chan JL \& Mantzoros CS 2002 Leptin and reproduction: a review. Fertility and Sterility 77 433-444.

Perez Martinez S, Franchi AM, Suburo A, Herrero B, Goin JC, Oshima H \& Gimeno MAF 1997 Several isoforms of nitric oxide synthase are present in the rat oviduct. Biocell 21 215-223.

Perez Martinez S, Franchi AM, Viggiano JM, Herrero MB \& Gimeno M 1998 Effect of prostaglandin F2 $\alpha$ (PGF2 $\alpha$ ) on oviductal nitric oxide synthase (NOS) activity: possible role of endogenous NO on PGF2 $\alpha$-induced contractions in rat oviduct. Prostaglandins and Other Lipid Mediators 56 155-166.

Perez Martinez S, Farina M, Ogando D, Ribeiro ML, Gimeno M \& Franchi AM 2000a Nitric oxide inhibits prostanoid synthesis in the rat oviduct. Prostaglandins, Leukotrienes and Essential Fatty Acids 62 239-242.

Perez Martinez S, Franchi AM, Herrero MB, Gimeno M \& Villalon M $2000 b$ Effect of nitric oxide synthase inhibitors on ovum transport and oviductal smooth muscle activity in the rat oviduct. Journal of Reproduction and Fertility 118 111-117.

Ribeiro ML, Cella M, Farina M \& Franchi AM 2003 Crosstalk between nitric oxide synthase and cyclooxygenase metabolites in the estrogenized rat uterus. Prostaglandins, Lenkotrienes and Essential Fatty Acids 68 285-290.

Rommers JM, Boiti C, Brecchia G, Meijerhof R, Noordhuizen JPTM, Decuypere E \& Kemp B 2004 Metabolic adaptation and hormonal regulation in young rabbit does during long-term caloric restriction and subsequent compensatory growth. Animal Science $\mathbf{7 9}$ 255-264.

Rosselli M, Dubey RK, Rosselli MA, Macas E, Fink D, Lauper U, Keller PJ \& Imthurn B 1996 Identification of nitric oxide synthase in human and bovine oviduct. Molecular Human Reproduction 2 607-612.

Ryan NK, Woodhouse CM, Van der Hoek KH, Gilchrist RB, Armstrong DT \& Norman RJ 2002 Expression of leptin and its receptor in the murine ovary: possible role in the regulation of oocyte maturation. Biology of Reproduction 66 1548-1554.

Sales KJ \& Jabbour HN 2003 Cyclooxygenase enzymes and prostaglandins in reproductive tract physiology and pathology. Prostaglandins and Other Lipid Mediators 71 97-117.

Salvemini D 1997 Regulation of cyclooxygenase enzymes by nitric oxide. Cellular and Molecular Life Science 53 576-582.
Sayegh R \& Mastroianni L Jr 1991 Recent advances in our understanding of tubal function. Annals of New York Academy of Sciences 626 266-275.

Smith-Kirwin SM, O'Connor DM, Johnston J, De Lancey E, Hassink SG \& Funanage VL 1998 Leptin expression in the human mammary cells and breast milk. Journal of Clinical Endocrinology and Metabolism 83 1810-1812.

Sokal RR \& Rohlf FJ 1981 Biometry. The Principles and Practice of Statistics in Biological Research, edn 2. New York: WH Freeman and Company.

Spicer LJ \& Francisco CC 1997 The adipose obese gene product, leptin: evidence of a direct inhibitory role in ovarian function. Endocrinology 138 3374-3379.

Steiner J, LaPaglia N, Kirsteins L, Emanuele M \& Emanule N 2003 The response of the hypothalamic-pituitary-gonadal axis to fasting is modulated by leptin. Endocrine Research 29 107-117.

Sweeney G 2002 Leptin signalling. Cellular Signalling 14 655-663.

Tsuda K, Kimura K \& Nishio I 2002 Leptin improves membrane fluidity of erythrocytes in humans via a nitric-oxide mechanism an electron paramagnetic resonance investigation. Biochemical and Biophysical Research Communications 297 672-681.

Watanabe H \& Sciöth HB 2001 Nitric oxide mediates leptin-induced preovulatory luteinizing hormone and prolactin surges in rats. Brain Research 923 193-197.

Wijayagunawardane MP, Gabler C, Killian C \& Miyamoto A 2003 Tumor necrosis factor alpha in the bovine oviduct during the estrous cycle: messenger RNA expression and effect on secretion of prostaglandins, endothelin-1, and angiotensin II. Biology of Reproduction 69 1341-1346.

Williams GL, Amstalden M, Garcia MR, Stanko RL, Nizielski SE, Morrison CD \& Keisler DH 2002 Leptin and its role in the central regulation of reproduction in cattle. Domestic Animal Endocrinology 23 339-349.

Wollenhaupt K, Tomek W, Brussow KP, Tiemann U, Viergutz T, Schneider F \& Nurnberg G 2002 Effects of ovarian steroids and epidermal growth factor (EGF) on expression and bioactivation of specific regulators of transcription and translation in oviductal tissue in pigs. Reproduction 123 87-96.

Zerani M, Boiti C, Zampini D, Brecchia G, Dall'Aglio C, Ceccarelli P \& Gobbetti A $2004 \mathrm{Ob}$ receptor in rabbit ovary and leptin in vitro regulation of corpora lutea. Journal of Endocrinology 183 279-288.

Zhang Y, Proenca R, Maffei M, Barone M, Leopold L \& Friedman JM 1994 Positional cloning of the mouse obese gene and its human homologue. Nature 372 425-432.

Received in final form 11 January 2005

Accepted 1 February 2005

Made available online as an

Accepted Preprint 11 February 2005 